\title{
VIABILITAS BAKTERI PROBIOTIK IN-VIT RO DAN PENGARUH PEMBERIAN AIR OKSIGEN TERHADAP PERTUMBUHAN BAKTERI PROBIOTIK SECARA IN-VIVO
}

\author{
(Viability of Probiotic Bacterialn-Vitro and the Effect of Oxygenated Water \\ On Viability of Probiotic Bacteria in Vivo)
}

Enok Sobariah $^{1}$, Ali Khomsan ${ }^{2}$ dan Ingrid S. Surono ${ }^{3}$

\begin{abstract}
ABST RACT
The aim of this study were to identify the in-vitro tolerance of pro-biotic bacteria to acid and bile salt condition; and to prove a hypothesis that the supplementation of oxygenated water has a positive effect on the body weight of rat and on viability of probiotic bacteria. The first study was carried out at PAU Laboratory of Bogor Agricultural University, while the second study was conducted at Department of Community Nutrition of Bogor Agricultural University and Microbiology Laboratory of Indonesia Institute of Technology. Forty five rats aged 6 weeks were divided into three groups, i.e., control group without probiotic (a0), Lactobacillus casei Shirota (a1), and Lactobacillus IS-7257 (a2). Each group (consisting of 5 rats each) has three different treatments, namely, control without oxygenated water (b0), $50 \mathrm{ppm}$ oxygenated water (b2), and $80 \mathrm{ppm}$ oxygenated water (b2). Oxygenated water was administered to the rats twice a day in the morning $(3.25 \mathrm{ml})$ and afternoon $(3.00 \mathrm{ml})$. Observation was carried out on the body weight of the rats, fecal lactic acid bacteria, coliform, and anaerob bacteria by plate counting, for 4 periods, i.e, prior to the treatment $(\mathrm{CO})$, after three-day treatment $(\mathrm{C} 1)$, after seven-day treatment (C2), and on the $10^{\text {th }}$ day treatment or three days after washed out period. The results indicated that probiotic bacteria are resistant to acid and bile acid condition. Oxygen concentration in water has a significant positive influence on the body weight of rats towards viability of probiotic bacteria ( $p$-level $<0.05$ ). The supplementation of oxygenated water $50 \mathrm{ppm}$ significantly increase the population of viable fecal lactic acid bacteria in L. casei Shirota and Lactobacillus IS-7257 groups after 3 and 7 days of treatment. Lactobacillus IS-7257 gave better response than L. casei Shirota. The supplementation of oxygenated water $80 \mathrm{ppm}$ significantly reduces the fecal coliform in-vivo in both L. casei Shirota and Lactobacillus IS-7257 groups ( $p$-level <0.05).
\end{abstract}

Keywords: oxygenated water, probiotic bacteria, viability

\section{PENDAHULUAN}

\section{Latar Belakang}

Air merupakan unsur yang sangat penting dalam semua kehidupan. Hampir semua metabolisme zat gizi di dalam tubuh memerlukan air. Selain berfungsi untuk transportasi zat gi$z i$, air juga bermanfaat untuk pengeluaran zatzat racun atau sisa hasil pencernaan. Selain itu juga berfungsi untuk keseimbangan fungsi tubuh dan mengatur suhu tubuh.

Selain air, unsur yang tidak kalah pentingnya dalam kehidupan adalah oksigen. Oksigen diperlukan untuk proses pembakaran dalam tubuh, yaitu mengubah zat-zat gizi menjadi energi yang diperlukan oleh tubuh untuk

\footnotetext{
${ }^{1}$ Alumni Program Studi Sekolah Pascasarjana Gizi Masyarakat IPB.

${ }^{2}$ Staf Pengajar Departemen Gizi Masyarakat, Fakultas Ekologi Manusia (FEMA), IPB.

${ }^{3}$ Staf Pengajar SEAMEO TROPMED UI
}

melakukan aktivitas sehari-hari. Hipoksia atau kekurangan oksigen ditingkat jaringan merupakan penyebab utama terjadinya penyakit degeneratif.

Penelitian tentang air beroksigen telah menghasilkan temuan yang menarik dari sisi ilmiah. Hipotesis bahwa oksigen dalam air beroksigen akan mempengaruhi pertumbuhan ataupun akan meracuni mikroba yang bermanfaat atau bakteri probiotik tidak terbukti. Pada kultur Lactobacillus casei strain Shirota, penambahan $\mathrm{O}_{2}$ 30-35 ppm menghasilkan kultur dengan populasi bekteri asam laktat yang jauh lebih tinggi dibandingkan kontrol (Rumawas, Ahza, Elizabeth, \& Dewanti, 2004).

Probiotik adalah bakteri "baik" yang harus mencapai saluran pencernaan dalam keadaan hidup dengan jumlah yang cukup guna menghasilkan efek kesehatan yang positif. Probiotik menghasilkan metabolit yaitu asam organik, hidrogen peroksida, karbondioksida dan 
senyawa bersifat antimikroba terhadap bakteri patogen. Bakteri ini mampu mengikat senyawa racun hasil metabolisme protein dan lemak, serta hasil pemecahan enzim tertentu, sehingga meringankan tugas organ hati (Salminen, Wright, dan Ouwenhand, 2004).

Probiotik juga merupakan bakteri hidup yang dapat diberikan sebagai suplemen makanan. Pemberian probiotik dapat berpengaruh menguntungkan bagi kesehatan karena probiotik dapat menghasilkan asam lemak rantai pendek dan menyebabkan suasana usus menjadi asam sehingga menekan pertumbuhan bakteri patogen serta memperbaiki keseimbangan mikrobiota usus. Mikroflora yang digolongkan sebagai probiotik terutama adalah dari golongan Lactobacillus dan Bifidobacterium.

Pengendalian penyakit pada manusia dan ternak menggunakan probiotik telah dilakukan sejak lama dan terdokumentasi dengan baik (Fuller, 1987). Tikus merupakan hewan menyusui yang mempunyai peranan penting dalam kehidupan manusia, terutama dalam hal penggunaanya sebagai hewan percobaan di laboratorium, seperti tikus putih (Rattus norvegicus strain albino) atau mencit putih (strain albino) yang sering dijadikan hewan percobaan untuk menguji obat dan tingkat toksisitas racun hama terhadap manusia (Priyambodo, 2003), karena tikus merupakan hewan omnivore (pemakan segala) biasanya mau mengonsumsi semua makanan yang dapat dimakan oleh manusia, baik yang berasal dari tumbuhan maupun dari hewan. Tikus memiliki kesamaan saluran pencernaan dan proses metabolisme dengan manusia (Priyambodo, 2003).

Perubahan konsentrasi oksigen diduga akan meningkatkan aktivitas bakteri aerob maupun mikroaerofilik sehingga akan meningkatkan probiotik dalam tubuh.

\section{Tujuan Penelitian}

Tujuan penelitian ini dapat dirumuskan sebagai berikut:

1. Mengetahui toleransi bakteri probiotik terhadap kondisi asam dan garam empedu.

2. Mengetahui pengaruh oksigen dengan konsentrasi 50 ppm dan 80 ppm terhadap pertumbuhan berat badan tikus.

3. Mengetahui pengaruh air oksigen konsentrasi 50 ppm dan 80 ppm terhadap pertumbuhan bakteri asam laktat.

4. Mengetahui pengaruh air oksigen konsentrasi 50 ppm dan 80 ppm terhadap pertumbuhan bakteri coliform.

\section{METODE PENELITIAN}

\section{Desain, Tempat dan Waktu Penelitian}

Penelitian dilaksanakan selama satu bulan yang terbagi dalam dua tahapan percobaan, yaitu secara in-vitro untuk menguji ketahanan bakteri probiotik terhadap asam dan garam empedu yang dilakukan di laboratorium PAU IPB (Institut Pertanian Bogor), dan secara in-vivo menggunakan hewan percobaan tikus putih Spraque Dauley, dengan dua jenis kultur bakteri asam laktat yaitu Lactobacillus casei Shirota, dan Lactobacillus IS-7257 yang dilakukan di laboratorium hewan GMSK IPB (Institut Pertanian Bogor), analisis mikrobiologi dilakukan di laboratorium mikrobiologi ITI (Institut Teknologi Indonesia).

Ada tiga variabel perlakuan yang diberikan pada uji in-vivo yaitu AirOx (air beroksigen) konsentrasi 0 ppm, 50 ppm dan 80 ppm. Parameter yang diamati adalah berat tubuh tikus, jumlah mikrobiologi yaitu jumlah fekal bakteri asam laktat, bakteri fekal coliform, dan bakteri fekal anaerob.

\section{Bahan dan Alat}

Penelitian ini menggunakan hewan percobaan tikus putih Spraque Dauley yang berasal dari Bali Penelitian Veteriner Boor. Kultur bakteri asam laktat yaitu Lactobacillus casei Shirota dan Lactobacillus IS-7257 berasal dari hasil penelitian Dr. Ingrid S Surono. Bahan Iain yang digunakan dalam penelitian ini yaitu air oksigen konsentrasi 50 ppm dan 80 ppm. Bahan yang dipakai untuk ransum hewan percobaan meliputi tepung maizena, casein, CMC, vitamin, mineral, dan minyak jagung mazola.

Analisis uji viabilitas in-vitro menggunakan bahan-bahan MRSA, MRSB, Iarutan $\mathrm{HCl} 10 \%$ dan $0.5 \%$ garam empedu. Untuk analisis mikrobiologi in-vivo digunakan bahan kultur Lactobacillus casei Srirota, Lactobacillus IS-7257, air oksigen konsentrasi 50 ppm dan konsentrasi 80 ppm, media MRSA (untuk bakteri asam laktat), media VRBA (untuk bakteri coliform). Berbagai peralatan yang digunakan dalam penelitian ini tercantum pada Tabel 1.

\section{Pelaksanaan Penelitian}

\section{Uji in-vitro}

Kultur kering beku ditumbuhkan dalam MRSB selama 24 jam pada suhu 37으, kemudian diinokulasi ke MRSB selama 18 jam dan diatur pHnya menjadi pH 2, 3, dan 4 dengan menambahkan HCL. Kemudian di shaker selama 0 jam, 0.5 jam dan 1 jam, jumlah sel hidup di- 
Tabel 1. Berbagai Alat Bantu Penelitian

\begin{tabular}{|c|c|c|c|}
\hline No & Tempat & Alat & Fungsi \\
\hline \multirow[t]{4}{*}{1} & \multirow[t]{4}{*}{ Laboratorium GMSK } & Timbangan analitik & $\begin{array}{l}\text { - Menimbang berat tikus } \\
\text { - Menimbang feses } \\
\text { - Menimbang pakan }\end{array}$ \\
\hline & & Anaerob jar & $\begin{array}{l}\text { Alat penyimpan dan membawa sampel steril } \\
\text { bersifat anaerob }\end{array}$ \\
\hline & & Seperangkat inkubator & $\begin{array}{l}\text { - tempat inkubasi } \\
\text { - Tempat perlakuan steril }\end{array}$ \\
\hline & & $\begin{array}{l}\text { Seperangkat Iamina dan } \\
\text { Seperangkat oven }\end{array}$ & $\begin{array}{l}\text { Untuk persiapan media tumbuh bakteri } \\
\text { VRBA, MRNA, PCA. }\end{array}$ \\
\hline 2 & $\begin{array}{l}\text { Laboratorium } \\
\text { Mikrobiologi }\end{array}$ & $\begin{array}{l}\text { Aotoclaf } \\
\text { Cawan petri, tabung reaksi }\end{array}$ & \\
\hline
\end{tabular}

tumbuhkan pada MRSA pada pengenceran tertentu, kemudian diinkubasi pada suhu $37^{\circ} \mathrm{C}$ selama 48 jam, dan dihitung jumlah bakteri yang bertahan hidup (modifikasi Zavaglia et al., 1998).

Kultur kering beku ditumbuhkan dalam MRSB selama 24 jam pada suhu $37^{\circ} \mathrm{C}$, kemudian diinokulasi ke MRSB selama 18 jam pada suhu $37^{\circ} \mathrm{C}$. Untuk mengetahui ketahanan terhadap garam empedu, maka dibandingkan probiotik yang tumbuh pada MRSB + bile $0.5 \%$ sebagai perlakuan dan tanpa bile sebagai pembanding. Setelah itu dilakukan inkubasi selama 48 jam pada suhu $37^{\circ} \mathrm{C}$, kemudian dihitung jumlah sel hidup pada masing-masing cawan (Zavaglia et al., 1998).

\section{Uji in-vivo}

Binatang percobaan tikus Spraque Dauley (SD) dimasukan ke dalam kandang metabolik dan dikelompokkan menjadi 3 kelompok, masing-masing 15 ekor, kelompok kontrol ( $\mathrm{A} 0$ ) tanpa bakteri probiotik, kelompok probiotik Lactobacillus casei Shirota (A1) dan kelompok probiotik Lactobacillus IS-7257 (A2), ada tiga variabel perlakuan, yaitu tanpa air oksigen (B0) sebagai kontrol, pemberian AirOx konsentrasi 50 ppm (B1), dan AirOx konsentrasi 80 ppm (B2), sehingga terbentuk suatu model percobaan :

- AOBO : tanpa bakteri probiotik dan tanpa air oksigen

- A0B1 : tanpa bakteri probiotik dengan penambahan air oksigen 50 ppm

- A0B2 : tanpa bakteri probiotik dengan penambahan air oksigen 80 ppm

- A1B0 : dengan bakteri probiotik 1 tanpa penambahan air oksigen

- AlB1 : dengan bakteri probiotik 1 dengan air oksigen 50 ppm

- A1B2 : dengan bakteri probiotik 1 dengan air oksigen 80 ppm

- A2B0 : dengan bakteri probiotik 2 tanpa penambahan air oksigen
- A2B1 : dengan bakteri probiotik 2 dengan air oksigen 50 ppm

- A2B2 : dengan bakteri probiotik 2 dengan air oksigen 80 ppm

Probiotik diberikan satu kali setiap pagi hari sebanyak $10 \mathrm{mg}$, sedangkan air oksigen diberikan 2 kali , pagi 3,25 $\mathrm{ml}$ dan sore $3 \mathrm{ml}$, dengan cara dicekok atau dipaksa.

Variabel yang diamati adalah berat tubuh tikus dan fekal bakteri yaitu asam laktat, bakteri coliform. Pengamatan dilakukan pada periode 0 hari (C0), 3 hari (C1), 7 hari (C2) dan 10 hari (C3).

\section{Analisis mikrobiologi}

Fekal segar dimasukkan ke dalam anaerob jar kemudian dianalisis di laboratorium dengan cara : sampel dipipet sebanyak $1 \mathrm{ml}$ ke dalam larutan buffer (phosphate buffet saline) steril dengan pH 6.8 sebanyak $9 \mathrm{ml}$, kemudian di-vortex agar homogen, dilakukan pengenceran sesuai dengan yang diinginkan, lalu diplating dan dilakukan pemupukan pada cawan petri steril menggunakan MRSA untuk asam laktat dan VRBA untuk coliform. Selanjutnya diinkubasi pada suhu $37^{\circ} \mathrm{C}$, kemudian jumlah koloni dihitung setelah 48 jam (metode Standard Plate Count).

\section{Rancangan Percobaan dan Analisis Statistik}

Model matemetika yang digunakan dalam penelitian ini adalah:

\footnotetext{
$\mathbf{Y i j k}=\mu+\alpha \mathbf{i}+\beta \mathbf{j}+(\alpha \beta) \mathbf{i j}+\varepsilon \mathbf{i j k}$

Yijk =nilai pengamatan pada faktor A taraf ke-i, faktor B taraf ke-j, dan ulangan ke-k

$\mu \quad=$ rataan dari perlakuan

ai = pengaruh utama faktor $A$

$\beta \mathrm{j} \quad=$ pengaruh utama faktor $B$

$(\alpha \beta)$ ij = komponen interaksi dari faktor $\mathrm{A}$ dan faktor B
} 
zijk = pengaruk acak yang menyebar nor$\operatorname{mal}\left(0, \sigma^{2}\right)$

A = perlakuan penambahan probiotik

B = perlakuan penambahan air oksigen

i $\quad=3$ taraf (1: tanpa penambahan probiotik, 2: penambahan Lactobacillus casei Shirota, 3 : penambahan Lactobacillus IS-7257)

j $\quad=3$ taraf (1: tanpa air oksigen, 2: air oksigen 50 ppm, 3 : air oksigen 80 ppm)

$k=5$ ulangan ( 5 ekor tikus untuk setiap perlakuan)

Metode yang di pakai dalam penelitian eksperimental ini adalah case control dengan uji statistik ANOVA untuk mengetahui pengaruh perlakuan yang digunakan terhadap variabel yang diamati. Sementara untuk uj i lanjutnya digunakan uji beda nyata terkecil (LSD).

\section{HASIL DAN PEMBAHASAN}

\section{Uji In-vitro}

Hasil penelitian menunjukkan bahwa IS7257 lebih tahan terhadap asam dan garam empedu dibandingkan dengan L. casei Shirota (Tabel 2).

Tabel 2. Ketahanan Bakteri Probiotik terhadap Asam

\begin{tabular}{|c|c|c|c|}
\hline \multirow{2}{*}{$\mathbf{p H}$} & \multirow{2}{*}{$\begin{array}{c}\text { Waktu } \\
\text { (jam) }\end{array}$} & \multicolumn{2}{|c|}{$\begin{array}{c}\text { J umlah bakteri (log } \\
\text { cfu/ml) }\end{array}$} \\
\cline { 3 - 4 } & & $\begin{array}{c}\text { L. casei } \\
\text { Shirota }\end{array}$ & IS-7257 \\
\hline \multirow{3}{*}{2} & 0 & 7.11 & 8.45 \\
\cline { 2 - 4 } & 0.5 & 0 & 5.23 \\
\cline { 2 - 4 } & 1 & 0 & 5.05 \\
\hline \multirow{3}{*}{3} & 0 & 9.11 & 10.70 \\
\cline { 2 - 4 } & 0.5 & 9.37 & 8.54 \\
\cline { 2 - 4 } & 1 & 9.45 & 9.68 \\
\hline \multirow{3}{*}{4} & 0 & 9.48 & 9.68 \\
\cline { 2 - 4 } & 0.5 & 9.06 & 9.79 \\
\cline { 2 - 4 } & 1 & 9.63 & 9.84 \\
\hline
\end{tabular}

Tabel 3. Ketahanan Probiotik terhadap Garam Empedu

\begin{tabular}{|l|c|c|}
\hline \multirow{2}{*}{\multicolumn{1}{|c|}{ Perlakuan }} & \multicolumn{2}{c|}{$\begin{array}{c}\text { J umlah bakteri (log } \\
\text { cfu/ml) }\end{array}$} \\
\cline { 2 - 3 } & $\begin{array}{c}\text { L. casei } \\
\text { Shirota }\end{array}$ & IS-7257 \\
\hline MRSA & 9.50 & 9.44 \\
\hline MRSA + garam empedu & 0 & 9.37 \\
\hline
\end{tabular}

Berdasarkan data pada Tabel 2 diketahui L. casei Shirota pada $\mathrm{pH} 2$ hanya tahan selama 0 jam, pada $\mathrm{pH} 3$ dan $\mathrm{pH} 4$ dapat bertahan selama 0.5 dan 1 jam, sedangkan L. IS-7257 dapat bertahan pada $\mathrm{pH} 2, \mathrm{pH} 3$ dan $\mathrm{pH} 4$ selama 0 jam, 0.5 jam dan 1 jam.

J adi dapat disimpulkan kedua jenis bakteri ini memenuhi syarat sebagai probiotik, yang diharapkan akan mampu melewati saluran pencernaan dengan berbagai cairan pencernaan yang disekresikan oleh organ pencernaan dengan kondisi asam. Toleransi terhadap asam merupakan salah satu syarat penting suatu isolat untuk dapat menjadi probiotik, yaitu harus mampu bertahan pada $\mathrm{pH}$ asam lambung sekitar 3.5 (Kimoto at al., 1999).

Bakteri probiotik L. IS-7257 mampu hidup pada media yang mengandung garam empedu $0.5 \%$ hampir tidak mengalami perubahan atau penurunan. Hasil penelitian ini sesuai dengan pernyataan Kimoto et al. (1999), Zavaglia et al. (1998), dan J acobsen et al. (1999), yaitu semua mikroba yang berhasil hidup setelah ditumbuhkan pada media MRSA yang ditambah $0.5 \%$ garam empedu dinyatakan bersifat tahan terhadap garam empedu. Bakteri L. casei Shirota dari hasil analisis hanya tahan pada media MRSA $9.5 \mathrm{log} / \mathrm{ml}$, dan tidak tahan pada media MRSA + bile.

\section{Uji in-vivo}

\section{Berat Badan Tikus}

Tabel 4 menunjukkan bahwa semua tikus berat badannya meningkat baik kelompok perlakuan maupun kontrol, pada periode pengamatan hari ke-3, 7 dan 10 hari.

Hasil analisis ragam menunjukkan bahwa jenis probiotik, konsentrasi air oksigen, periode pengamatan maupun interaksinya nyata berpengaruh pada pertumbuhan berat badan tikus $(p<0.05)$. Hasil uji lanjut beda nyata terkecil (LSD) menunjukkan bahwa perlakuan A1B0 berbeda dengan A1B1 dan A1B2. Pengamatan periode hari ke 0 berbeda dengan hari ke 3 , ke 7 dan hari ke 10 , sedangkan hari ke 7 tidak berbeda dengan hari ke 10 .

Lactobacillus casei Shirota (A1) dengan tanpa penambahan air oksigen memberikan pengaruh penambahan berat badan yang lebih baik pada periode pengamatan hari ke 3 , ke 7 , dan ke $10(p<0.05)$. Dalam penelitian ini intake makanan tidak dihitung, sedangkan Mc Donald, Adwards dan Greenhalgh (1973) menyatakan bahwa untuk pertumbuhan dan perkembangan tikus harus ada kecukupan nutrisi dalam ransum sehingga berpengaruh positif 
pada pertambahan berat badan tikus. Berapapun kadar oksigen yang diberikan terhadap tikus tidak memberikan efek penambahan berat badan yang signifikan apabila konsumsi zat gizi kurang.

Tabel 4. Delta Perubahan Berat Badan Tikus

\begin{tabular}{|c|c|c|c|c|}
\hline \multirow{2}{*}{ Perlakuan } & \multicolumn{4}{|c|}{ Periode Pengamatan } \\
\cline { 2 - 5 } & 0 hari & $\mathbf{3}$ hari & 7 hari & 10 hari \\
\hline A0B0 & 0 & 5.52 & 20.3 & 28.06 \\
\hline A0B1 & 0 & 8.78 & 19.26 & 24.8 \\
\hline A0B2 & 0 & 4.46 & 12.26 & 21.6 \\
\hline A1B0 & 0 & 8.26 & 21.92 & 28.38 \\
\hline A1B1 & 0 & 2.78 & 10.7 & 10.54 \\
\hline A1B2 & 0 & 2.82 & 9.58 & 10.48 \\
\hline A2B0 & 0 & 6.38 & 16.3 & 20.9 \\
\hline A2B1 & 0 & 0.65 & 18.66 & 16.35 \\
\hline A2B2 & 0 & 7.44 & 15.9 & 21.2 \\
\hline
\end{tabular}

Keterangan:

AOBO : tanpa bakteri probiotik dan tanpa air oksigen

A0B1 : tanpa bakteri probiotik dengan penambahan air oksigen 50 ppm

AOB2 : tanpa bakteri probiotik dengan penambahan air oksigen 80 ppm

A1B0 : dengan bakteri Lactobacillus casei Shirota tanpa penambahan air oksigen

A1B1 : dengan bakteri Lactobacillus casei Shirota dan dengan air oksigen 50 ppm

A1B2 : dengan bakteri Lactobacillus casei Shirota dan dengan air oksigen 80 ppm

A2B0 : dengan bakteri Lactobacillus IS-7257 tanpa penambahan air oksigen

A2B1 : dengan bakteri Lactobacillus IS-7257 dan dengan air oksigen 50 ppm

A2B2 : dengan bakteri Lactobacillus IS-7257 dan dengan air oksigen 80 ppm

\section{Total Bakteri Fekal Asam Laktat}

Hasil analisis ragam menunjukkan bahwa interaksi antara jenis probiotik, air oksigen dan periode pengamatan berpengaruh nyata terhadap total bakteri fekal asam laktat. $(p<$ 0.05). Perlakuan L. casei Shirota dan L. IS-7257 dengan konsentrasi 50 ppm dan 80 ppm memberikan pengaruh yang nyata terhadap kenaikan jumlah asam laktat. L. IS 7257 dengan konsentrasi air oksigen 50 ppm lebih baik jika dibandingkan dengan air oksigen konsentrasi 80 ppm dalam penambahan jumlah bakteri asam laktat $(p<0.05)$.

Uji Ianj ut beda terkecil (LSD) menunjukkan bahwa pengamatan hari ke- 0 berbeda dengan hari ke-3, hari ke-3 berbeda dengan hari ke-7, dan hari ke-3 berbeda dengan hari ke-10.
Pengamatan yang paling baik pada hari ke 3 $(p \measuredangle 0.05)$. Rata-rata jumlah asam laktat dengan berbagai perlakuan tersaj i pada Tabel 5 .

Tabel 5. Delta Perubahan J umlah Bakteri Asam Laktat

\begin{tabular}{|c|c|c|c|c|}
\hline \multirow{2}{*}{ Perlakuan } & \multicolumn{4}{|c|}{ Periode pengamatan } \\
\cline { 2 - 5 } & 0 hari & $\mathbf{3}$ hari & $\mathbf{7}$ hari & $\mathbf{1 0}$ hari \\
\hline A0B0 & 0 & -0.61 & -0.71 & -0.87 \\
\hline A0B1 & 0 & -0.11 & -0.04 & -0.91 \\
\hline A0B2 & 0 & -0.05 & -0.01 & -0.08 \\
\hline A1B0 & 0 & 0.78 & 0.93 & 0.84 \\
\hline A1B1 & 0 & 1.62 & 1.56 & 0.86 \\
\hline A1B2 & 0 & 1.38 & 1.35 & 0.17 \\
\hline A2B0 & 0 & 3.42 & 1.41 & 0.76 \\
\hline A2B1 & 0 & 3.25 & 1.76 & 1 \\
\hline A2B2 & 0 & 0.45 & 2.27 & -1.19 \\
\hline
\end{tabular}

Keterangan:

AOB0 : tanpa bakteri probiotik dan tanpa air oksigen

A0B1 : tanpa bakteri probiotik dengan penambahan air oksigen 50 ppm

A0B2 : tanpa bakteri probiotik dengan penambahan air oksigen 80 ppm

A1B0 : dengan bakteri Lactobacillus casei Shirota tanpa penambahan air oksigen

A1B1 : dengan bakteri Lactobacillus casei Shirota dan dengan air oksigen 50 ppm

A1B2 : dengan bakteri Lactobacillus casei Shirota dan dengan air oksigen 80 ppm

A2B0 : dengan bakteri Lactobacillus IS-7257 tanpa penambahan air oksigen

A2B1 : dengan bakteri Lactobacillus IS-7257 dan dengan air oksigen 50 ppm

A2B2 : dengan bakteri Lactobacillus IS-7257 dan dengan air oksigen 80 ppm

Pada pengamatan hari ke 3, perlakuan A2B0 berbeda dengan A2B2 dan perlakuan A2B2 berbeda dengan A2B1. Interaksi antara Lactobacillus IS-7257 dengan konsentrasi air oksigen 50 ppm (A2B1) memberikan respon lebih baik dibandingkan dengan konsentrasi oksigen 80 ppm (A2B2) dan kontrol.

Hasil penelitian ini memberikan gambaran bahwa total fekal asam laktat yang diamati selama perlakuan mencerminkan total bakteri asam laktat probiotik yang bersifat homofermentatif.

Bakteri probotik yang bersifat homofermentatif dalam proses metabolismenya akan menghasilkan 85\% asam laktat sebagai produk metabolitnya, sehingga asam laktat yang dihasilkan mampu memberikan suasana asam (Surono, 2004). Hal ini akan memberikan res- 
pon yang positif terhadap mikroflora pada saluran pencernaan karena bakteri patogen tidak tahan terhadap kondisi asam atau pH di bawah 3.5 (Kimoto at al., 2005), sehingga bakteri probiotik dapat mendominasi saluran cerna dan memperbaiki saluran pencernaan.

Pemberian Lactobacillus IS-7257 (A2) meningkatkan total bakteri fekal asam laktat (cfu/gram feces) selama perlakuan yaitu pada pengamatan hari ke 3 (C1) dan pengamatan hari ke 7 (C2). Setelah hari ke 10 rata-rata total bakteri fekal asam lakat menurun kembali.

Kehadiran oksigen berperan sebagai eksternal elektron akseptor, sehingga meningkatkan produksi asam piruvat hasil fermentasi karbohidrat, dalam hal ini glukosa (Axelsson 2004), untuk selanjutnya menambah jumlah ATP, dan mempercepat pertumbuhan bakteri asam laktat. Dengan adanya suplai oksigen maka pertumbuhan bisa melalui jalur metabolisme aerobik, sehingga menghasilkan ATP lebih banyak. Satu molekul glukosa menghasilkan 38 ATP dengan produk akhir asam laktat yang tentu saja akan semakin meningkatkan laju pertumbuhannya mengingat jenis probiotik yang digunakan pada uji in-vivo ini ádalah homofermentatif (Surono, 2004).

Hasil penelitian ini didukung juga dengan adanya interaksi nyata antara probiotik, konsentrasi air oksigen dan periode pengamatan, yang berarti suplemen probiotik bersama-sama dengan air oksigen berpengaruh positif terhadap total bakteri fekal asam laktat. Interaksi antara probiotik dengan periode perlakuan memperlihatkan pengaruh nyata yang positif dalam meningkatkan total bakteri fekal asam laktat selama periode perlakuan.

\section{Total Bakteri Fekal Coliform}

Hasil analisis ragam menunjukkan bahwa jenis probiotik, konsentrasi air oksigen dan interaksinya berpengaruh nyata pada total bakteri fekal coliform $(p \varangle 0.05)$. Interaksi konsentrasi air oksigen dan periode pengamatan berpengaruh nyata terhadap penurunan total bakteri fekal coliform ( $p$-level <0.05). Uji lanjut terkecil menunjukkan bahwa pengamatan hari ke-0 berbeda nyata dengan hari ke-3 dan ke-7.

Hasil analisis ragam menunjukkan bahwa perlakuan kontrol tanpa penambahan probiotik (A0) berbeda nyata dengan perlakuan Lactobacillus casei Shirota (A1) dan Lactobacillus IS7257 (A2) dalam memberikan pengaruh terhadap total bakteri fekal coliform. AOBO dan $A 0 B 1$ berbeda nyata terhadap A0B2. Perlakuan A1B0 berbeda nyata terhadap A1B1, dan A1B1 berbeda nyata dengan A1B2. Perlakuan A2B0 berbeda nyata dengan A2B1 dan A2B2. Periode pengamatan hari ke 0 berbeda dengan hari ke 3 dan ke 10 ( $p<0.05)$.

Konsentrasi pemberian air oksigen 50 ppm berbeda nyata dengan 80 ppm. Pemberiaan air oksigen 80 ppm lebih baik dalam menurunkan jumlah bakteri coliform. Interaksi yang terbaik dalam menurunkan bakteri coliform adalah L. casei Shirota dengan air oksigen konsentrasi 80 ppm (A1B2) $(p \nless 0.05)$.

Rata-rata jumlah bakteri coliform tersaj i pada Tabel 5. Pada Tabel 3 terlihat bahwa total bakteri fekal coliform terendah ditemukan pada perlakuan penambahan Lactobacillus casei Shirota dengan air oksigen 80 ppm (A1B2) pada hari pengamatan ke 3. Hal ini menunjukkan bahwa bakteri probiotik Lactobacillus casei Shirota (A1) lebih mampu berkompetisi dengan bakteri coliform dibandingkan dengan Lactobacillus IS-7257, sehingga dapat menekan jumlah coliform.

Tabel 5. Delta Perubahan Bakteri Coliform (log $\mathrm{cfu} / \mathrm{g}$ )

\begin{tabular}{|c|c|c|c|c|}
\hline \multirow{2}{*}{ Perlakuan } & \multicolumn{4}{|c|}{ Periode pengamatan } \\
\cline { 2 - 5 } & 0 hari & $\mathbf{3}$ hari & $\mathbf{7}$ hari & 10 hari \\
\hline A0B0 & 0 & -0.48 & -0.68 & 0.21 \\
\hline A0B1 & 0 & -0.12 & 0.33 & 0.41 \\
\hline A0B2 & 0 & -1.25 & -1.54 & -1.01 \\
\hline A1B0 & 0 & -1.26 & -1.49 & -1.06 \\
\hline A1B1 & 0 & -1.31 & -0.17 & -0.28 \\
\hline A1B2 & 0 & -1.46 & -1.24 & -1.25 \\
\hline A2B0 & 0 & -1.92 & -1.31 & -1.8 \\
\hline A2B1 & 0 & -0.3 & -0.25 & -0.61 \\
\hline A2B2 & 0 & -1.38 & 6.46 & -1.49 \\
\hline
\end{tabular}

Keterangan:

AOB0 : tanpa bakteri probiotik dan tanpa air oksigen

A0B1 : tanpa bakteri probiotik dengan penambahan air oksigen 50 ppm

A0B2 : tanpa bakteri probiotik dengan penambahan air oksigen 80 ppm

A1B0 : dengan bakteri Lactobacillus casei Shirota tanpa penambahan air oksigen

A1B1 : dengan bakteri Lactobacillus casei Shirota dan dengan air oksigen 50 ppm

A1B2 : dengan bakteri Lactobacillus casei Shirota dan dengan air oksigen 80 ppm

A2B0 : dengan bakteri Lactobacillus IS- 7257 tanpa penambahan air oksigen

A2B1 : dengan bakteri Lactobacillus IS-7257 dan dengan air oksigen 50 ppm

A2B2 : dengan bakteri Lactobacillus IS-7257 dan dengan air oksigen 80 ppm 
Hal ini juga terjadi atas peran bakteri probiotik yang mampu berkompetisi dan mampu menempel pada sel epithelial, sehingga berkesempatan untuk menjalankan perannya sebagai probiotik, seperti berkompetisi terhadap coliform, dan mengeliminasi clostridium perfringens, dan clostridium difficile. Bakteri anaerob yang jumlahnya mendominasi populasi bakteri di saluran cerna menghasilkan toxin dan menyebabkan diare dan colitis (Mikelsaar et al., 2004).

\section{KESIMPULAN DAN SARAN}

\section{Kesimpulan}

Lactobacillus casei Shirota tahan terhadap kondisi asam pada pH3, namun pada media MRSA + bile $0.5 \%$ bakteri tersebut tidak tumbuh. Lactobacillus IS- 7257 pada pH 2 juga tahan pada media MRSA + bile 0,5\% secara invitro. Hal ini membuktikan bahwa kedua bakteri tersebut adalah bakteri probiotik.

Perlakuan Lactobacillus casei Shirota, baik tanpa penambahan air oksigen maupun dengan penambahan $50 \mathrm{ppm}$ dan $80 \mathrm{ppm}$ berpengaruh baik dalam meningkatkan berat badan tikus. Konsentrasi air oksigen 50 ppm lebih baik dibandingkan dengan $80 \mathrm{ppm}$ pada pengamatan hari ke 3,7 , dan $10(p<0.05)$.

J enis probiotik, periode pengamatan dan interaksinya nyata berpengaruh terhadap total bakteri asam laktat $(p<0.05)$. Konsentrasi air oksigen 50 ppm memberikan hasil yang lebih baik dibandingkan air oksigen 80 ppm. Respon paling baik pada perlakuan Lactobacillus IS7257 dengan konsentrasi 50 ppm (A2B1) pada pengamatan hari ke 3 dan hari ke-7.

Jenis probiotik, konsentrasi air oksigen dan periode pengamatan berpengaruh positif dalam penekanan bakteri coliform $(p<0.05)$. Respon yang paling baik pada Lacto- bacillus casei Shirota dengan konsentrasi air oksigen 80 ppm (A1B2) pada periode penga- matan hari ke 3, dan 7 .

Pemberian probiotik dan air oksigen mempunyai manfaat masing-masing meningkatkan bakteri probiotik dan menurunkan bakteri coliform secara in-vivo, sehingga diharapkan akan membantu meningkatkan kesehatan saluran pencernaan, agar penyerapan nutrisi lebih baik.

\section{Saran}

Hasil uji in-vivo ini menunjukkan bahwa konsentrasi air oksigen 50 ppm berpengaruh baik terhadap pertumbuhan bakteri asam laktat, konsentrasi oksigen 80 ppm baik terhadap penekanan total bakteri fekal coliform dan penekanan bakteri anaerob, maka untuk lebih ideal perlu dilakukan penelitian lajutan secara klinis ter- hadap manusia agar diketahui dosis optimum pada manusia.

\section{DAFTAR PUSTAKA}

Fuller R. 1989. Probiotik in man and animals. J Appl Bacteriol, 66, 365-378.

Jacobsen CN, Nielsen VR, Hayford AE, Moller $\mathrm{PL}$, Michaelsen $\mathrm{KF}$, Erregaard $\mathrm{AP}$, Sansdtrom B, Tvede $M \&$ \& Jakobsen $M$. 1999. Screening of probiotic activities of forty-seven strains of Lactobacillus spp. By in vitro techniques and evaluation of the colonization ability of five selected strain in humans. J Appl and Environ, 65, 4949-4956.

Kimoto H, Kurisaki J, Tsuji Mn, Ohmomo S, \& Okamoto T. 1999. Lactococci asprobiotic strains: adhesion to human enterocytelike caco-2 cells and tolerans to low $\mathrm{pH}$ and bile. Lett in Appl Microbiol, 29, 313316.

McDonald P, Adwards RA, \& Greenhalgh J FD. 1973. Animal Nutrition Fifth Edition. Longman Group Ltd, London, 221 - 237.

Priyambodo S. 2003. Pengendalian Hama Tikus. Penebar Swadaya, J akarta.

Rumawas F, Basuki A, Elizabeth R, Dewanti R. 2004. Pengaruh AirOx terhadap Bakteri asam laktat Probiotik. Bogor.

Salminen S, Wright AV, \& Ouwenhand A. 2004. Lactic Acid Bacteria Microbiology and Fungtional aspects. Marcel Dekker, New York. Pp 211- 254.

Surono. 2004. Probiotik Susu Fermentasi dan Kesehatan, YAPMMY. ISBN 979-98871.

Zavaglia AG, Kociubinski G, Perez $P, \&$ Antoni GD. 1998. Isolation and Characterization of Bifidobacterium Strains of Probiotik Formulation. J Food Protect, 61(7), 865873. 
J urnal Gizi dan Pangan, Maret 2007 2(1): 22-28 